\title{
Biochemical responses in lettuce subjected to salinity and the application of purple lettuce extract
}

Respostas bioquímicas em alface submetida à salinidade e à aplicação de extrato de alface roxa

\author{
C. Deuner ${ }^{1 *}$; G. E. Meneghello후 C. I. S. Castellanos ${ }^{1}$; C. T. Borges ${ }^{1}$; S. Deuner ${ }^{2}$ \\ ${ }^{1}$ Postgraduate program in Seed Science and Technology, Federal University of Pelotas, 9616-000, Pelotas-RS, Brazil \\ ${ }^{2}$ Department of Botany, Federal University of Pelotas, 9616-000, Pelotas-RS, Brazil
}

*cdeuner@yahoo.com.br

(Recebido em 13 de novembro de 2019; aceito em 15 de junho de 2020)

\begin{abstract}
Antioxidants are substances that present in low concentrations, compared to the oxidizable substrate, significantly delay or inhibit the oxidation of the substrate, which can be induced by several stress factors, such as salinity. The purple varieties of lettuce have high antioxidant activity because of the large amount of anthocyanins they possess. The objective of this study was to analyze biochemical responses in lettuce seedlings submitted to saline stress and to the application of aqueous extract of leaves of purple lettuce. Seeds of lettuce, cv. Regina, which were cultivated in polystyrene trays, being submitted to irrigation with extracts of purple lettuce and saline solutions during the early stages of seedling development. The parameters evaluated were: chlorophyll index, flavonoids, anthocyanins and nitrogen balance, sodium content, osmotic potential, hydrogen peroxide, lipid peroxidation and enzyme activity superoxide dismutase, ascorbate peroxidase and catalase. The extract of purple lettuce leaves is efficient to reduce oxidative stress in lettuce seedlings, in saline environment.

Keywords: antioxidant activity, saline stress, tolerance.
\end{abstract}

Os antioxidantes são substâncias que presentes em baixas concentrações, comparativamente ao substrato oxidável, retardam significativamente ou inibem a oxidação do substrato, que pode ser induzido por diversos fatores de estresse, como a salinidade. As variedades roxas da alface possuem alta atividade antioxidante pela grande quantidade de antocianinas que possuem. Objetivou-se analisar respostas bioquímicas em plântulas de alface submetidas à estresse salino e à aplicação de extrato aquoso de folhas de alface roxa. Utilizaram-se sementes de alface, cv. Regina, as quais foram cultivadas em bandejas de poliestireno, sendo submetidas à irrigação com extratos de alface roxa e soluções salinas durante os estágios iniciais de desenvolvimento das plântulas. Os parâmetros avaliados foram: índices de clorofila, flavonoides, antocianinas e o balanço de nitrogênio, teor de sódio, potencial osmótico, peróxido de hidrogênio, peroxidação de lipídios e atividade das enzimas superóxido dismutase, ascorbato peroxidase e catalase. $\mathrm{O}$ extrato de folhas de alface roxa é eficiente para reduzir o estresse oxidativo em plântulas de alface, em ambiente salino.

Palavras-chave: atividade antioxidante ,estresse salino, tolerância.

\section{INTRODUCTION}

Antioxidants are substances that present in low concentrations, compared to the oxidizable substrate, significantly delay or inhibit the substrate oxidation [1] which can be induced by several stress factors, such as, for example, salinity, which in certain conditions can cause oxidative stress.

Plants, in its turn, have antioxidative defense systems present in several subcellular compartments, which are usually sufficient to prevent oxidative damage during periods of growth under normal and moderate stress conditions [2]. However, if severely stressed, there is an increase in the generation of reactive oxygen species (ROS) and other oxidizing compounds, due to the accumulation of reactive intermediates, impairing the antioxidant defense system and the ability to repair oxidative damage [3]. ROSs are necessary for the plants development, but in high concentrations they can lead to oxidative damage in various cellular components, such as proteins, lipids and DNA, interrupting the vital cellular functions of plants [4].

Vegetables have numerous phytochemicals groups that are recognized for their antioxidant activity. Carotenoids have the polyene chain as a structural characteristic and may present cyclic

$$
061501-1
$$


terminal groups, with substituents containing oxygen. The conjugated and electron-rich system of the polyene is responsible for its antioxidant activity, which in addition to the absorption of singlet oxygen $\left({ }^{1} \mathrm{O}_{2}\right)$ [5], inhibits lipid peroxidation at low oxygen pressures [6]. Likewise, anthocyanins and flavonoids widely distributed in nature, in addition to physiological effects, have antioxidant activity [7].

Lettuce is a vegetable widely consumed in Brazil and very nutritious, as its leaves are rich in folate (vitamin B9), in addition to containing $\beta$-carotene, vitamin $\mathrm{C}$, potassium and certain phytochemicals, such as flavonoids and lactucine, compounds that favor their remarkable antioxidant capacity [8]. The purple variety may have greater antioxidant activity, justified by a large amount of anthocyanins present in this variety [9].

According to Selene et al. (2009) [10], several plant extracts have been studied due to their antioxidant power, as they help to reduce lipid oxidation in the tissues of plants and animals, under stress conditions. Studying the application of carrot root extract in inducing tolerance to salinity in cowpea seedlings, Abbas and Akladious (2013) [11] found that carrot extract as a solution for seed immersion is effective in overcoming stress saline in the seedlings, increasing the levels of antioxidant enzymes.

Studying extracts that help plants to overcome salt stress is important since the mechanisms of tolerance to salinity in vegetables are not yet fully understood by the fact that they involve biochemical, physiological and molecular changes [12]. In this sense, the objective was to analyze biochemical responses in lettuce seedlings submitted to salt stress and to the application of aqueous extract of purple lettuce leaves.

\section{MATERIAL AND METHODS}

The experiment was conducted in a greenhouse and analysis carried out at the Plant Nutrition Laboratory of the Department of Botany, Institute of Biology, and Soil Laboratory, Federal University of Pelotas (UFPel), Pelotas-RS.

Commercial seeds of lettuce cv. Regina were sown in polystyrene trays of 72 cells each, containing washed and autoclaved sand substrate. After germination, thinning was carried out keeping one seedling per cell, each treatment consisting of four replications of 18 seedlings. At the time of sowing and at four, nine, 15 and 22 days later, were applied $15 \mathrm{~mL} \mathrm{cell}^{-1}$ of solution composed of sodium chloride $(\mathrm{NaCl})$ in concentrations of $0,30,60,90$ and $120 \mathrm{mM}$ and aqueous extract of purple lettuce in concentrations of 0,75 and $125 \mathrm{~g}$ of $\mathrm{L}^{-1}$ leaves of water, each factor being applied in isolated and combined. In addition, Hoagland's nutrient solution [13] was administered, applying $10 \mathrm{~mL}$ at half strength at seven and 11 days after sowing and $6 \mathrm{~mL}$ at full strength, at 16 and 20 days after sowing. Whenever necessary, the seedlings were irrigated with water with the aid of a watering pot.

To obtain the aqueous extract of purple lettuce, leaves were washed with distilled water and dried with paper towels, then weighed according to the respective concentrations and crushed in a blender in the presence of 1 liter of distilled water and the extract filtered on filter paper.

At 24 days after sowing, the chlorophyll (CI), flavonoids (FI), anthocyanins (AI) and nitrogen balance (NB) indices were evaluated with the aid of the Dualex FORCE-A chlorophyll meter (Orsay, France) in 15 plants per treatment, placing the device reader in the adaxial region of the leaf. Subsequently, the seedlings were collected and evaluated for: a) Sodium content: quantified by the atomic absorption method, from the dry mass of the aerial part of the plants dried in an oven at $70{ }^{\circ} \mathrm{C}$ for 48 hours, according to the methodology described by Tedesco et al. (1995) [14]; b) Osmotic potential ( $\Psi \mathrm{s})$ : approximately $300 \mathrm{mg}$ of plant tissue (whole seedling) were macerated in polypropylene tubes, followed by centrifugation at $12,000 \mathrm{~g}$ at $4^{\circ} \mathrm{C}$ for 20 minutes. The recovered supernatant was analyzed in a vapor pressure osmometer model 5600 VAPRO (Wescor, Logan, Utah, USA). The values obtained in mmol kg${ }^{-1}$ were converted into $\Psi$ s using the Van't Hoff equation where $\Psi_{\mathrm{s}}=-\mathrm{C} \times 2.58 \times 10^{-3}, \mathrm{C}$ being the osmolality value obtained in $10 \mu \mathrm{L}$ of cellular juice in each measure; c) Lipid peroxidation: determined by measuring the concentration of species reactive to thiobarbituric acid (TBARS). Two hundred milligrams of leaf and root tissue were macerated in liquid nitrogen plus 20\% PVPP (polyvinylpolypyrrolidone) and homogenized in $0.1 \%(\mathrm{w} / \mathrm{v})$ trichloroacetic acid (TCA) solution. The homogenate was centrifuged 
at $10,000 \mathrm{~g}$ for 10 minutes. Then, $250 \mu \mathrm{L}$ of the supernatant was added to $1.0 \mathrm{ml}$ of the solution containing $0.5 \%(\mathrm{w} / \mathrm{v})$ thiobarbituric acid (TBA) and $10 \%(\mathrm{w} / \mathrm{v})$ TCA. The reaction medium was incubated at $95^{\circ} \mathrm{C}$ for 30 minutes keeping the tubes closed, stopping the reaction by rapid cooling in an ice and water bath.

The absorbance of the TBARS formed was determined in a spectrophotometer at $535 \mathrm{~nm}$ and $600 \mathrm{~nm}$. TBA forms reddish complexes with low molecular weight aldehydes, such as malondialdehyde (MDA), a secondary product of the peroxidation process. The concentration of the MDA/TBA complex was calculated using the equation: $[\mathrm{MDA}]=(\mathrm{A} 535-\mathrm{A} 600) /(\xi . \mathrm{b})$, where $\xi$ is the extinction coefficient $\left(1.56 \times 10^{-5} \mathrm{~cm}^{-1}\right)$ and $\mathrm{b}$ is the optical length $(\mathrm{b}=1)$. Peroxidation was expressed in nmol of fresh mass MDA g ${ }^{-1}$; d) Hydrogen peroxide $\left(\mathrm{H}_{2} \mathrm{O}_{2}\right)$ : determined according to the methodology described by Velikova et al. (2000) [15]; e) Specific activity of the antioxidant enzymes Superoxide dismutase (SOD), according to Giannopolitis and Ries (1977) [16]; Ascorbate peroxidase (APX) according to the methodology proposed by Nakano and Asada (1981) [17] and Catalase (CAT) determined as described by Azevedo et al. (1998) [18].

The experiment was conducted in a completely randomized design in a $3 \times 5$ factorial scheme (concentration of purple lettuce leaf extract $\mathrm{x}$ concentration of $\mathrm{NaCl}$ solution) with four replications. The data obtained were submitted to analysis of variance (ANOVA) by the F test ( $p$ $<0.05$ ). A comparison of means was performed by the test of the minimum significant difference $(\mathrm{p}<0.05)$ for the purple lettuce leaf extract concentration factor and polynomial regression $(\mathrm{p}<$ $0.05)$ for the $\mathrm{NaCl}$ solution concentration factor.

\section{RESULTS AND DISCUSSION}

According to the results obtained in the variance analysis, there was a significant interaction between the factors of lettuce extract and saline for the chlorophyll (CI), flavonoids (FI), anthocyanins (AI) and nitrogen balance (BN) indexes (Figure 1).

In the absence of the extract, the salt concentration factor did not influence the CI, however, with the application of 75 and $125 \mathrm{~g} \mathrm{~L}^{-1}$ of extract combined with $\mathrm{NaCl}$, there was an increase in the $\mathrm{CI}$ at a rate of 0.017 and 0.0193 units $\mathrm{mM}^{-1} \mathrm{NaCl}$, respectively. Analyzing the MSD, it can be observed that the applications of 75 and $125 \mathrm{~g} \mathrm{~L}^{-1}$ of extract were superior to the control in 120 $\mathrm{mM}$ of salt, with the concentration of $125 \mathrm{~g} \mathrm{~L}^{-1}$ also being higher in 30 and $90 \mathrm{mM}$, in relation to control (Figure 1A).

Lettuce is considered to be a relatively salt-sensitive vegetable [19], however, studies have shown that there is intraspecific variability [20] and, the increase in the levels of the photosynthetic pigment can be a mechanism of salinity tolerance, as observed in the present study and corroborated with those found by Paulus et al. (2010) [21] and Xu and Mou (2015) [19] in lettuce and by Silva et al. (2012) [22] in arugula. Still, based on the information in the literature and on the results obtained, it can be inferred that the extracts of purple lettuce help in some adaptive or protective process of the plant to salinity, allowing that, even in high concentrations of salt, the chlorophylls do not degrade.

$\mathrm{NaCl}$ solution did not influence the flavonoid index when the extract was applied, however, in its absence, there was an increase in the index at a rate of $0.0008 \mathrm{mM}^{-1} \mathrm{NaCl}$ units. Likewise, it was observed that the control $\left(0 \mathrm{~g} \mathrm{~L}^{-1}\right)$ was higher than the other two extract concentrations, regardless of the salt concentration, except for the $60 \mathrm{mM}$ concentration in which they did not differ statistically (Figure 1B). The anthocyanins index decreased by a rate of $0.0002 \mathrm{mM}^{-1}$ of $\mathrm{NaCl}$ applied in the absence and in the highest concentration of extract. In addition, it can be noted that there was a significant difference between extracts 0 and $125 \mathrm{~g} \mathrm{~L}^{-1}$ in all tested salt concentrations (Figure 1C). 

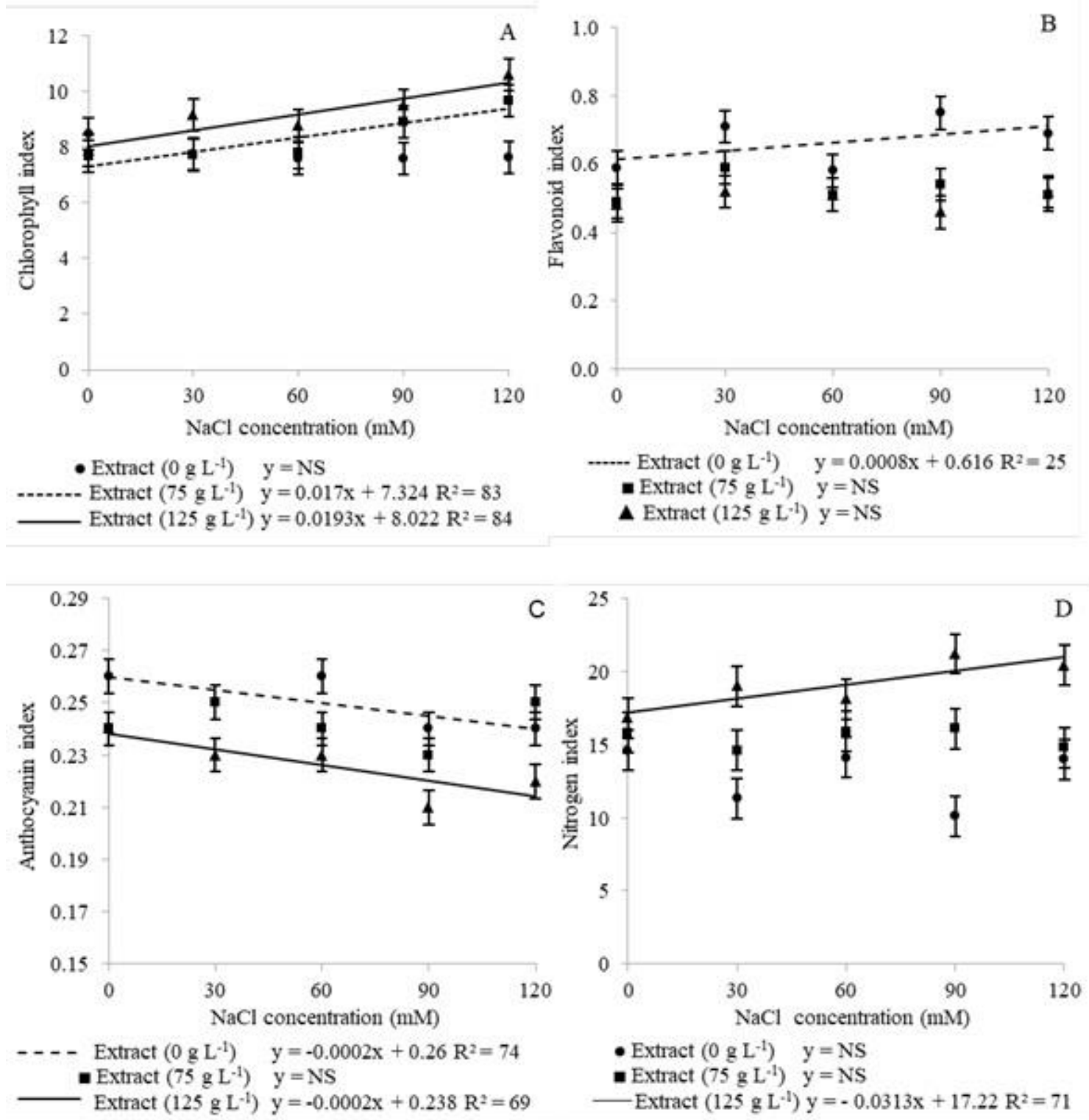

Figure 1: Index of chlorophyll (A), flavonoids $(B)$, anthocyanins $(C)$ and nitrogen balance $(D)$ in lettuce leaves from cultivated seedlings grown under different concentrations of purple lettuce leaf extract and $\mathrm{NaCl}$. The bars correspond to the MSD value (minimum significant difference) between the levels of the purple lettuce extract concentration factor, overlapping bars indicate that the treatments do not differ statistically.

The anthocyanins synthesis is directly related to the light incidence, nutritional balance, temperature changes during growth and ripening, and to the cultivation system itself, having established that agronomic practices that increase vegetative growth result in a the synthesis decrease of anthocyanins [23]. In the present study there was a reduction in the anthocyanins content as the salt concentration increased, and with the application of $125 \mathrm{~g} \mathrm{~L}^{-1}$ of purple lettuce leaf extract, the index was lower than the treatment without application of extract at all salinity levels (Figure 1C). The lettuce extract allowed greater vegetative growth of the seedlings (Figure 2), corroborating what was exposed by Severo et al. (2010) [23].

The application of purple lettuce extract at a concentration of $125 \mathrm{~g} \mathrm{~L}^{-1}$ increased the nitrogen balance with an increase in the salt concentration at a rate of $0.0313 \mathrm{mM}^{-1}$ units of $\mathrm{NaCl}$ (Figure 1D), with no differences in the other extract concentrations. Likewise, it was observed that the extract in the concentration of $125 \mathrm{~g} \mathrm{~L}^{-1}$ was higher than to the others in the concentrations of 30 , 90 and $120 \mathrm{mM}$ of $\mathrm{NaCl}$. The nitrogen balance in the seedlings increased with the application of $125 \mathrm{~g} \mathrm{~L}^{-1}$ of purple lettuce extract (Figure 1D). According to Esteves and Suzuki (2008) [24], 
tolerance to salinity in plants is related to the concentration of nitrogen compounds. According to these authors, the accumulation of amides, proteins, amino acids and polyamines in plants subjected to salt stress help in detoxifying cells, protecting macromolecules, maintaining cellular $\mathrm{pH}$, minimizing the effects of ROSs and regulating osmotic adjustment. This shows that the application of the extract of leaves of purple lettuce in a concentration of $125 \mathrm{~g} \mathrm{~L}^{-1}$ was able to reduce the stress caused by salt.

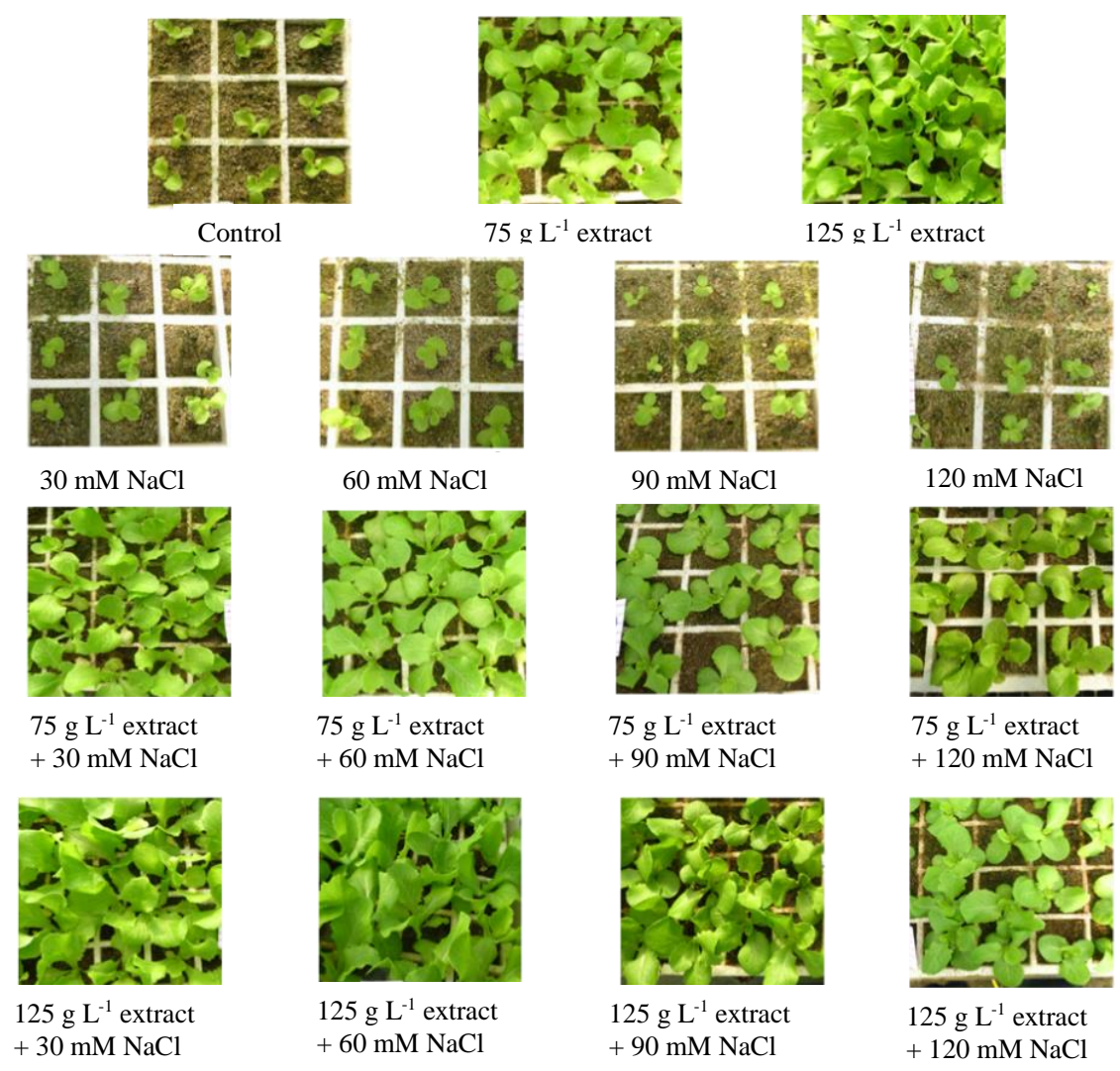

Figure 2: Lettuce seedlings, cv. Regina, grown under different concentrations of purple lettuce leaf extract and $\mathrm{NaCl}$.

The interaction of factors influenced the sodium content in the leaves. With the increase in the $\mathrm{NaCl}$ concentration, there was an increase in the sodium content in the leaves in the three concentrations of lettuce extracts tested, adjusting to mathematical models of a quadratic order (Figure 3). Analyzing the adjusted curves, it is observed that the control $\left(0 \mathrm{~g} \mathrm{~L}^{-1}\right)$ caused a maximum sodium content in the leaves of $9.27 \mathrm{~g} \mathrm{~kg}^{-1}$, a value reached in the $117.5 \mathrm{mM} \mathrm{NaCl}$ concentration. In extracts 75 and $125 \mathrm{~g} \mathrm{~L}^{-1}$ the maximum levels of sodium in the leaves were 7.3 and $8.32 \mathrm{~g} \mathrm{~kg}^{-1}$, which were reached in the concentrations of 81.06 and $96.5 \mathrm{mM} \mathrm{NaCl}$, respectively. These results indicate that the application of extract of leaves of purple lettuce in a concentration of $75 \mathrm{~g} \mathrm{~L}^{-1}$ decreases the sodium content in the leaves. 


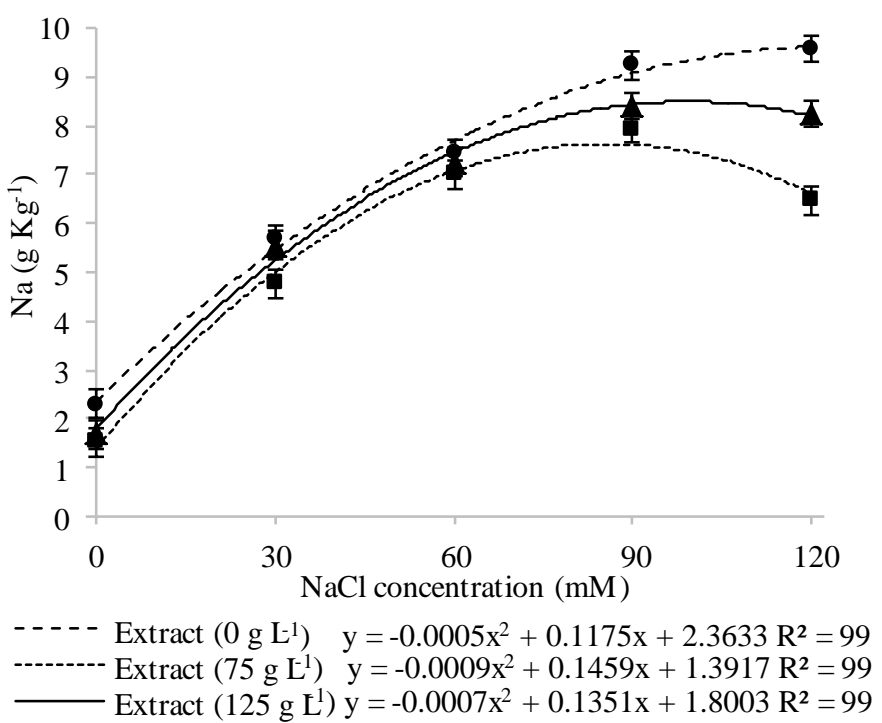

Figure 3: Leaf sodium content of lettuce plants grown under different concentrations of purple lettuce leaf extract and $\mathrm{NaCl}$. The bars correspond to the MSD value (minimum significant difference) between the levels of the purple lettuce extract concentration factor, overlapping bars indicate that the treatments do not differ statistically.

Paulus et al. (2012) [25] found an increase in the sodium content of lettuce leaves with the increase in the salinity levels in the water, results in agreement with those found in this experiment. On the other hand, Taiz and Zeiger (2013) [26] report that the absorption of salts by plants depends on the ability of the roots to prevent potentially harmful ions from reaching the aerial parts, so we can consider that the application of lettuce extract may have helped reducing the absorption of sodium by the roots and / or the translocation of the element to the aerial part of the seedlings.

Plant water uptake, the process modulating plant growth, is directly controlled by osmotic and matrix potential of soil water. Thus, the salinity of soil water is the most important factor determining its osmotic potential [27]. In the present study, the data obtained for the osmotic potential also showed a significant interaction between the factors. When applying the concentration of lettuce extract of $75 \mathrm{~g} \mathrm{~L}^{-1}$, the seedling osmotic potential adjusted to a negative linear model, decreasing at a rate of $0.002 \mathrm{MPa} \mathrm{mM}^{-1}$ of $\mathrm{NaCl}$. This behavior was also observed with the control extract, where the $\Psi$ s decreased at a rate of $0.0009 \mathrm{MPa} \mathrm{mM}^{-1}$ of $\mathrm{NaCl}$ (Figure 4). 


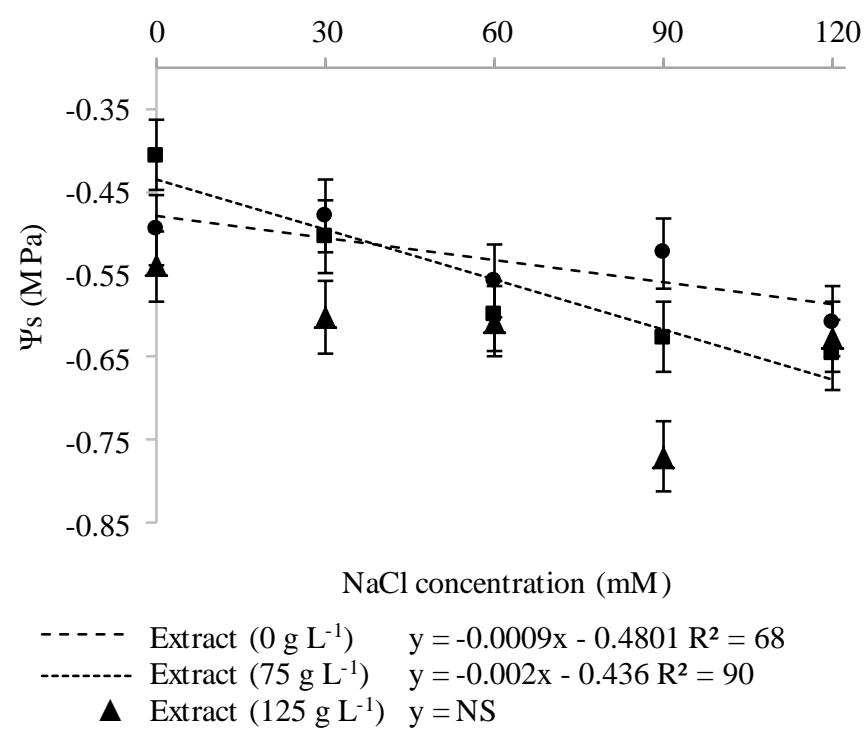

Figure 4: Osmotic potential of lettuce plants grown under different concentrations of purple lettuce leaf extract and $\mathrm{NaCl}$. The bars correspond to the MSD value (minimum significant difference) between the levels of the purple lettuce extract concentration factor, overlapping bars indicate that the treatments do not differ statistically.

The osmotic adjustment is considered to be an important component of salinity tolerance mechanisms in plants [28]. According to Willadino and Camara (2010) [29], osmotic adjustment is a process used by plants under salt stress conditions, in which there is an increase in the content of organic and inorganic solutes in the plant in order to reduce the water potential to a level lower than the soil, thus allowing the absorption of water and favoring the maintenance of the turgor. This process is visualized in Figure 4, where the osmotic potential of the plants decreases as the salt concentration increases, probably a product of the increase in the concentration of chlorophylls, nitrogen compounds and $\mathrm{Na}$ (Figures 1A, 1D and 3).

Lipid peroxidation, both in the aerial part and in the roots of the lettuce seedlings, was not influenced by the factors studied, according to the results of the variance analysis (Figure 5), demonstrating that there was no oxidative degradation of the lipids, which may be related to the protective mechanism triggered by the application of purple lettuce extract, leading to an increase in the pigment index and the efficient performance of antioxidant enzymes, as discussed below since several studies report an increase in the lipid peroxidation of lettuce under salt stress [30, $31,32,33]$. 


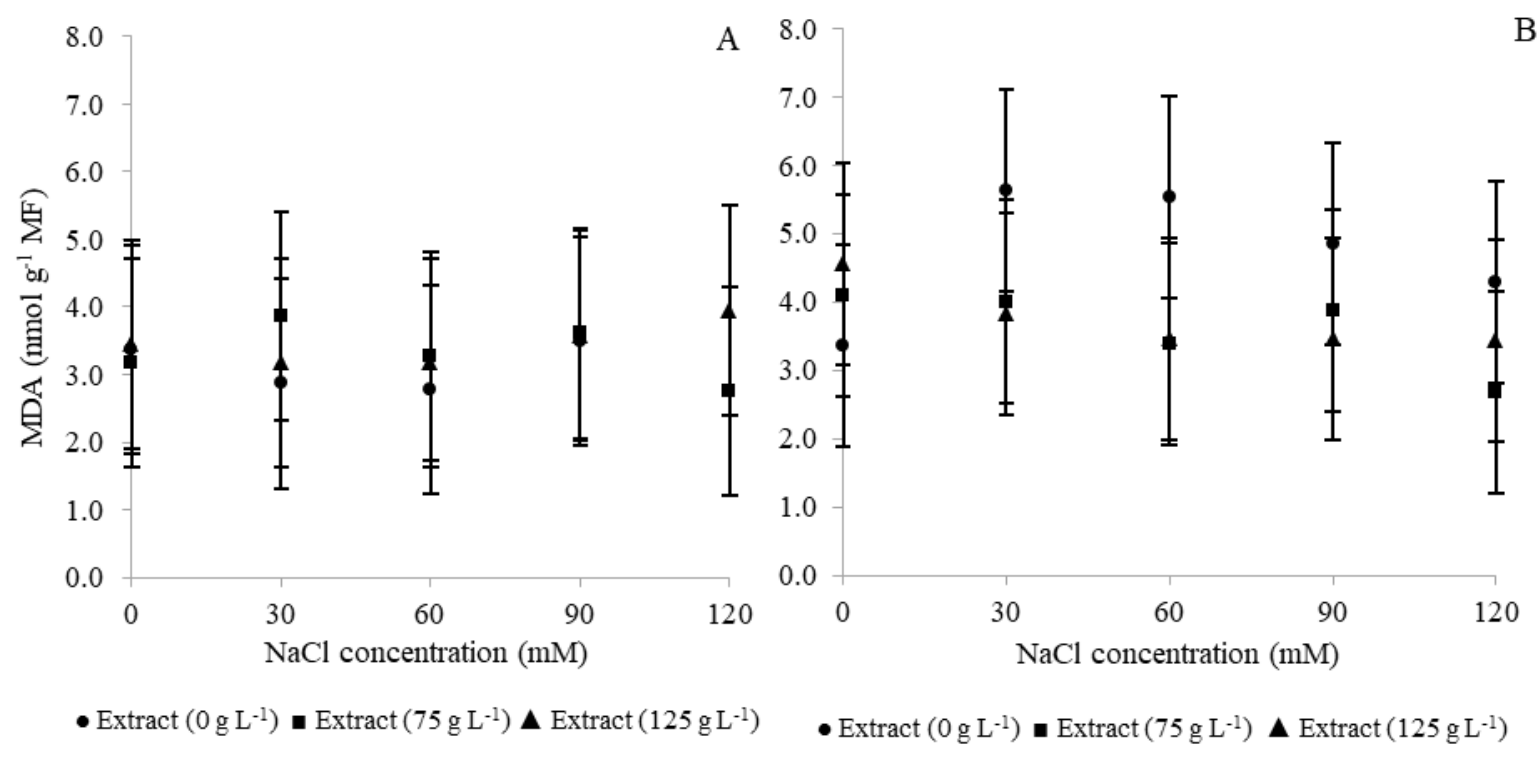

Figure 5: Lipid peroxidation in the aerial part $(A)$ and root $(B)$ of lettuce plants grown under different concentrations of purple lettuce leaf extract and $\mathrm{NaCl}$. The bars correspond to the MSD value (minimum significant difference) between the levels of the purple lettuce extract concentration factor, overlapping bars indicate that the treatments do not differ statistically.

The concentration of hydrogen peroxide in the aerial part of the lettuce seedlings showed a response to the factors interaction, while the roots showed a response only to the two isolated factors (Figure 6). In the aerial part, it was observed that with the application of $125 \mathrm{~g} \mathrm{~L}^{-1}$ of extract, the behavior of the variable adjusted to a negative quadratic model reaching a maximum point of $4.56 \mathrm{mmol}$ of $\mathrm{H}_{2} \mathrm{O}_{2} \mathrm{~g}^{-1} \mathrm{MF}$ in the concentration of $48,5 \mathrm{mM} \mathrm{NaCl}$. The same response was observed in the extract absence $\left(0 \mathrm{~g} \mathrm{~L}^{-1}\right)$, reaching a maximum point of $7.92 \mathrm{mmol} \mathrm{of} \mathrm{H}_{2} \mathrm{O}_{2} \mathrm{~g}^{-}$ ${ }^{1} \mathrm{MF}$ at a concentration of $65.8 \mathrm{mM} \mathrm{NaCl}$ (Figure 6A). It was also observed that the control extract was statistically superior to the others at concentrations 30,60 and $90 \mathrm{mM} \mathrm{NaCl}$ (Figure 6A).

In the root, the concentration of hydrogen peroxide increased as the concentration of $\mathrm{NaCl}$ increased at a rate of $0.0047 \mathrm{mmol} \mathrm{H}_{2} \mathrm{O}_{2} \mathrm{~g}^{-1} \mathrm{MF}$ per $\mathrm{mM}$ of $\mathrm{NaCl}$ administered (Figure 6B). In addition, the $\mathrm{H}_{2} \mathrm{O}_{2}$ concentration was higher when lettuce extract was not applied and lower when applying $75 \mathrm{~g} \mathrm{~L}^{-1}$ (Figure 6C). 

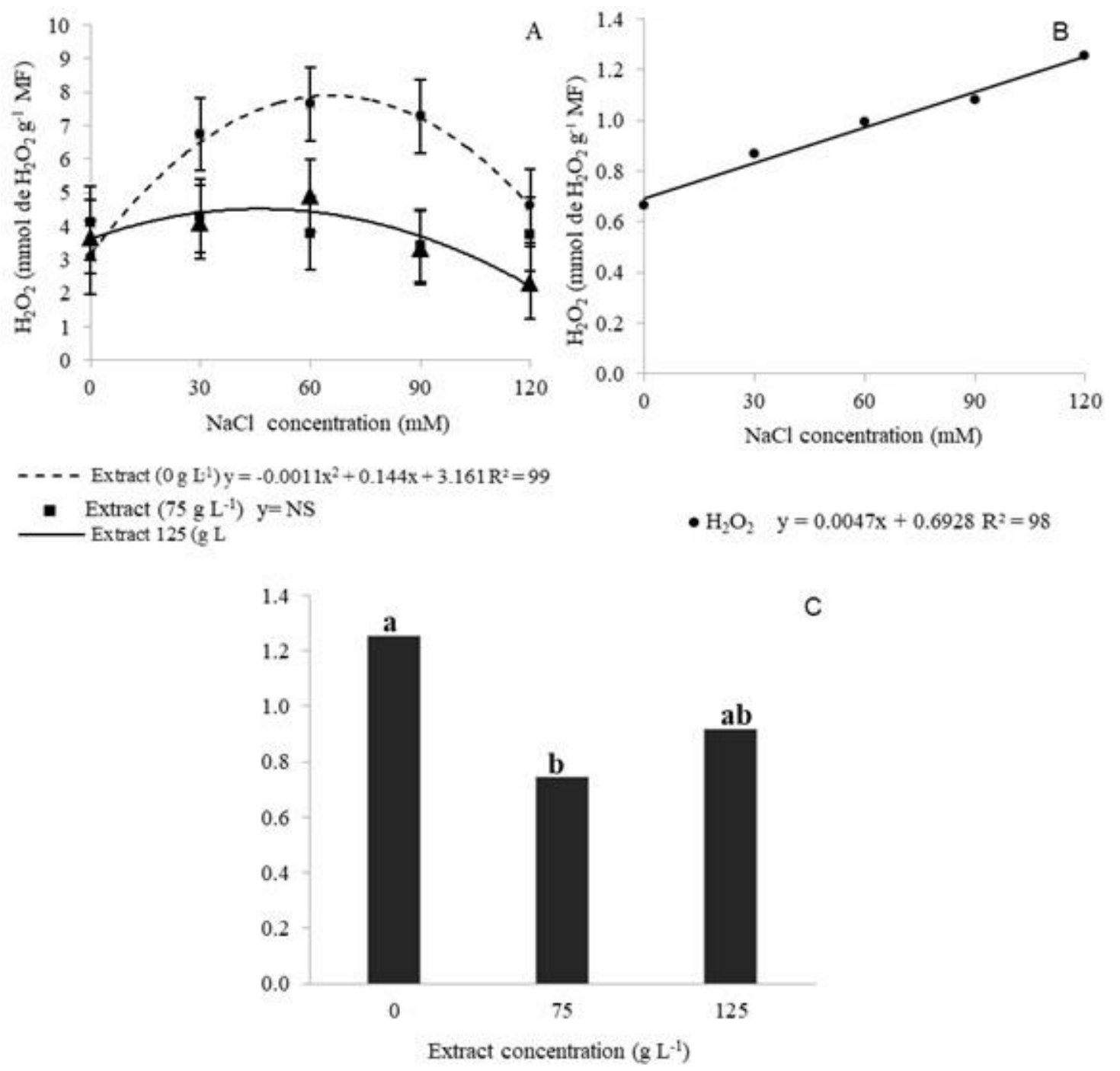

Figure 6: Hydrogen peroxide in the aerial part $(A)$ and root $(B, C)$ of lettuce plants grown under different concentrations of purple lettuce leaf extract and $\mathrm{NaCl}$. The bars correspond to the MSD value (minimum significant difference) between the levels of the purple lettuce extract concentration factor, overlapping bars indicate that the treatments do not differ statistically.

The behavior of the superoxide dismutase (SOD) enzyme in the aerial part of the lettuce seedlings was influenced by the concentration factors of lettuce extract and $\mathrm{NaCl}$, but not by the interaction between them, which occurred at the root of the seedlings. The SOD activity in the aerial part decreased with the increase of the salt concentration at a rate of $0.1526 \mathrm{U} \mathrm{mg}^{-1}$ of protein per $\mathrm{mM}$ of $\mathrm{NaCl}$ (Figure 7A). In addition, the enzyme showed less activity with the application of the lettuce extract, compared to the control (without application) (Figure 7B).

At the root, it was observed that without the extract application, the $\mathrm{NaCl}$ concentrations caused a quadratic type response, reaching a maximum peak of $291.33 \mathrm{U} \mathrm{mg}^{-1}$ of protein in the concentration of $62.2 \mathrm{mM} \mathrm{NaCl}$. With the application of $75 \mathrm{~g} \mathrm{~L}^{-1}$, the SOD behavior adjusted to a positive quadratic model, registering a minimum enzyme concentration of $104.5 \mathrm{U} \mathrm{mg}^{-1}$ of protein in the concentration of $41.5 \mathrm{mM} \mathrm{NaCl}$. The concentration of $125 \mathrm{~g} \mathrm{~L}^{-1}$ had no effect on the SOD behavior (Figure 7C). According to the MSD, the enzyme activity was lower with the applications of 75 and $125 \mathrm{~g} \mathrm{~L}^{-1}$ of extract, compared to the control, in the concentrations of 30 , 60 and $90 \mathrm{mM} \mathrm{NaCl}$ (Figure 7C). 

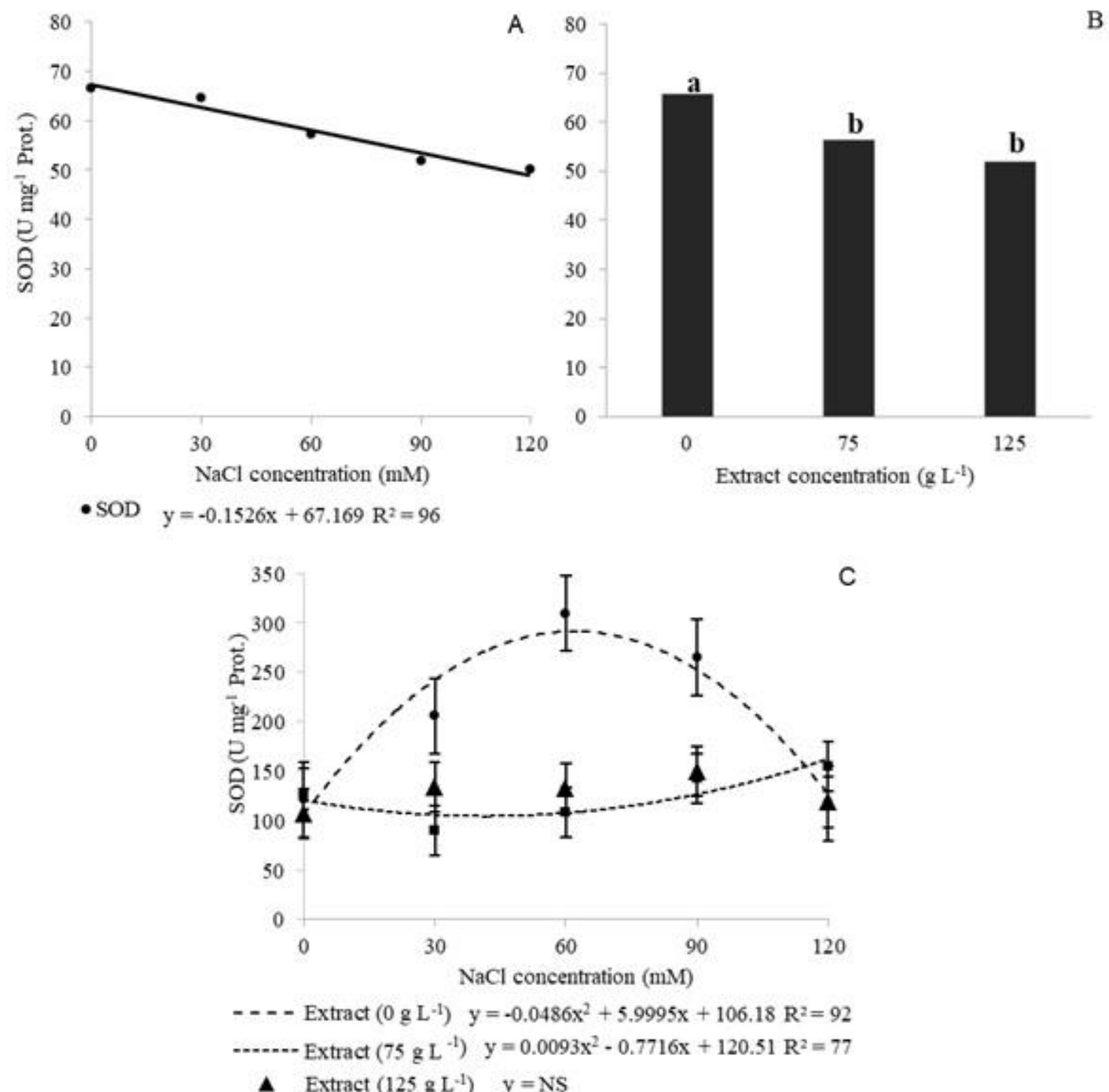

Figure 7: Superoxide dismutase (SOD) enzyme activity in the aerial part $(A, B)$ and root $(C)$ of lettuce plants grown under different concentrations of purple lettuce leaf extract and $\mathrm{NaCl}$. The bars correspond to the MSD value (minimum significant difference) between the levels of the purple lettuce extract concentration factor, overlapping bars indicate that the treatments do not differ statistically.

The activity of the enzyme ascorbate peroxidase (APX) in the aerial part of the seedlings was not influenced by the factors studied (Figure 8A). At the root, it showed a response to the interaction between factors. When applying the control extract, the enzyme activity adjusted to a negative quadratic model, reaching a maximum point of $89.7 \mathrm{mmol} \mathrm{ASA} \mathrm{min}^{-1} \mathrm{mg}^{-1}$ of protein at a concentration of $66.5 \mathrm{mM} \mathrm{NaCl}$. In the application of the $75 \mathrm{~g} \mathrm{~L}^{-1}$ extract, the APX activity adjusted to a positive linear model, increasing at a rate of $0.2089 \mathrm{mmol} \mathrm{ASA} \mathrm{min}{ }^{-1} \mathrm{mg}^{-1}$ of protein for each $\mathrm{mM}$ of $\mathrm{NaCl}$ added. As for the $125 \mathrm{~g} \mathrm{~L}^{-1}$ extract, the enzyme activity also adjusted to a negative quadratic model, reaching a maximum activity of $66.1 \mathrm{mmol} \mathrm{ASA} \mathrm{min}{ }^{-1} \mathrm{mg}^{-1}$ of protein at a concentration of $68.6 \mathrm{mM}$ of $\mathrm{NaCl}$ (Figure 8B). Likewise, it was observed that the APX activity was lower with the application of 75 and $125 \mathrm{~g} \mathrm{~L}^{-1}$ of extract in the concentration of 60 $\mathrm{mM}$ of salt, in relation to the control $\left(0 \mathrm{~g} \mathrm{~L}^{-1}\right)$. Response also observed in the concentration of 90 $\mathrm{mM}$, in which the application of $125 \mathrm{~g} \mathrm{~L}^{-1}$ of extract resulted in less activity of the enzyme in relation to the control (Figure $8 \mathrm{~B}$ ). 


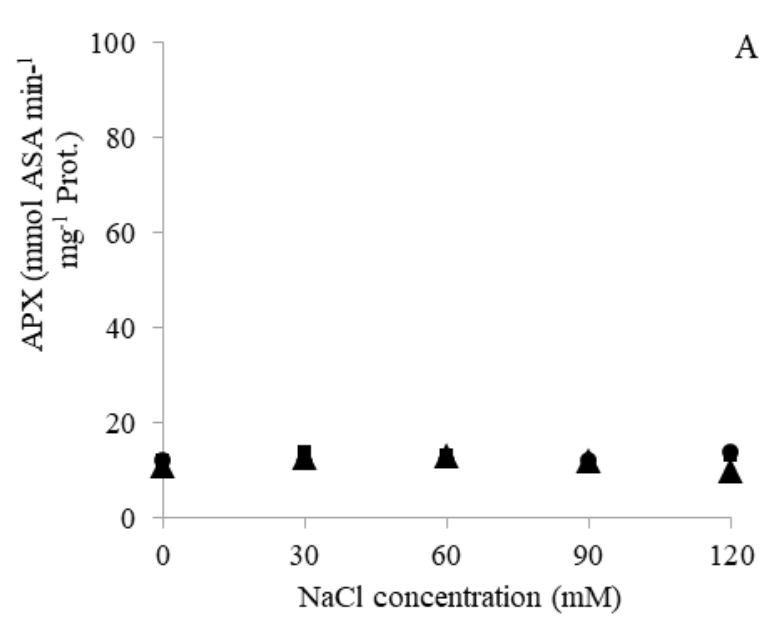

- Extract $\left(0 \mathrm{~g} \mathrm{~L}^{-1}\right) \quad \mathrm{y}=\mathrm{NS}$

- Extract $\left(75 \mathrm{~g} \mathrm{~L}^{-1}\right) \quad \mathrm{y}=\mathrm{NS}$

$\Delta$ Extract $\left(125 \mathrm{~g} \mathrm{~L}^{-1}\right) \mathrm{y}=\mathrm{NS}$

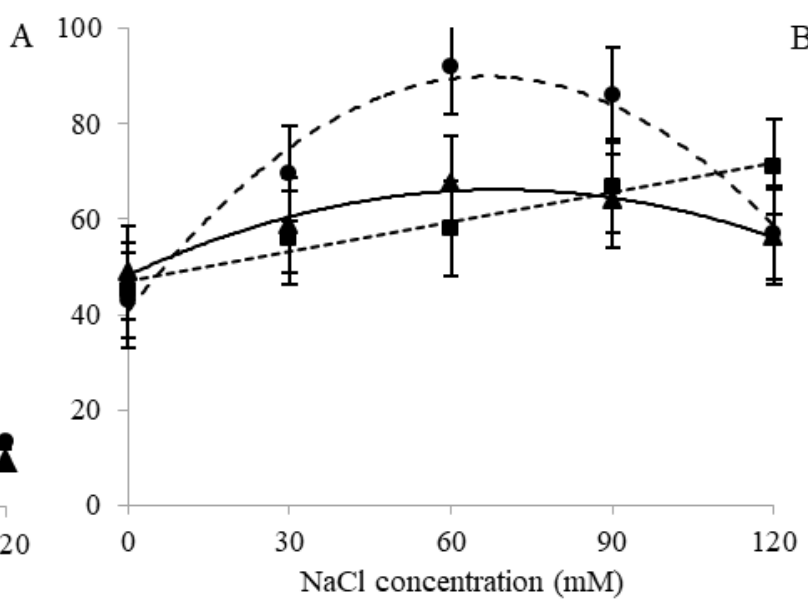

--- Extract $\left(0 \mathrm{~g} \mathrm{~L}^{-1}\right) y=-0.011 \mathrm{x}^{2}+1.475 \mathrm{x}+40.65 \mathrm{R}^{2}=97$
$\left.--1 \mathrm{~g} \mathrm{~L}^{-1}\right) \quad \mathrm{y}=0.2089 \mathrm{x}+46.855 \mathrm{R}^{2}=95$
Extract $\left(75 \operatorname{tract}\left(125 \mathrm{~g} \mathrm{~L}^{-1}\right) \mathrm{y}=-0.003 \mathrm{x}^{2}+0.52 \mathrm{x}+48.2 \mathrm{R}^{2}=97\right.$

Figure 8: Ascorbate peroxidase (APX) enzyme activity in the aerial part (A) and root (B) of lettuce plants grown under different concentrations of purple lettuce leaf extract and $\mathrm{NaCl}$. The bars correspond to the MSD value (minimum significant difference) between the levels of the purple lettuce extract concentration factor, overlapping bars indicate that the treatments do not differ statistically.

For catalase activity (CAT) (Figure 9), it is observed that in the aerial part of the seedlings, the enzyme showed a response only to the $\mathrm{NaCl}$ application, increasing its activity at a rate of 0.0858 $\mu$ mol $\mathrm{H}_{2} \mathrm{O}_{2}$ min-1 mg-1 of protein for each $\mathrm{mM}$ of $\mathrm{NaCl}$ added (Figure 9A). CAT activity at the root showed a response to the interaction of the studied factors. By applying the concentration of $0 \mathrm{~g} \mathrm{~L}^{-1}$ extract, CAT activity was adjusted to a negative quadratic model, reaching a peak of activity $22.2 \mathrm{ol} \mathrm{H}_{2} \mathrm{O}_{2} \mathrm{~min}^{-1} \mathrm{mg}^{-1}$ protein concentration in $101.3 \mathrm{mM} \mathrm{NaCl}$. However, the enzyme activity did not adjust to any mathematical model tested at the other concentrations (Figure 9B). Analyzing the MSD results, it was observed that from the $60 \mathrm{mM} \mathrm{NaCl}$ dose, the enzyme activity was higher in the control extract $\left(0 \mathrm{~g} \mathrm{~L}^{-1}\right)$ compared to the others (Figure $\left.9 \mathrm{~B}\right)$.

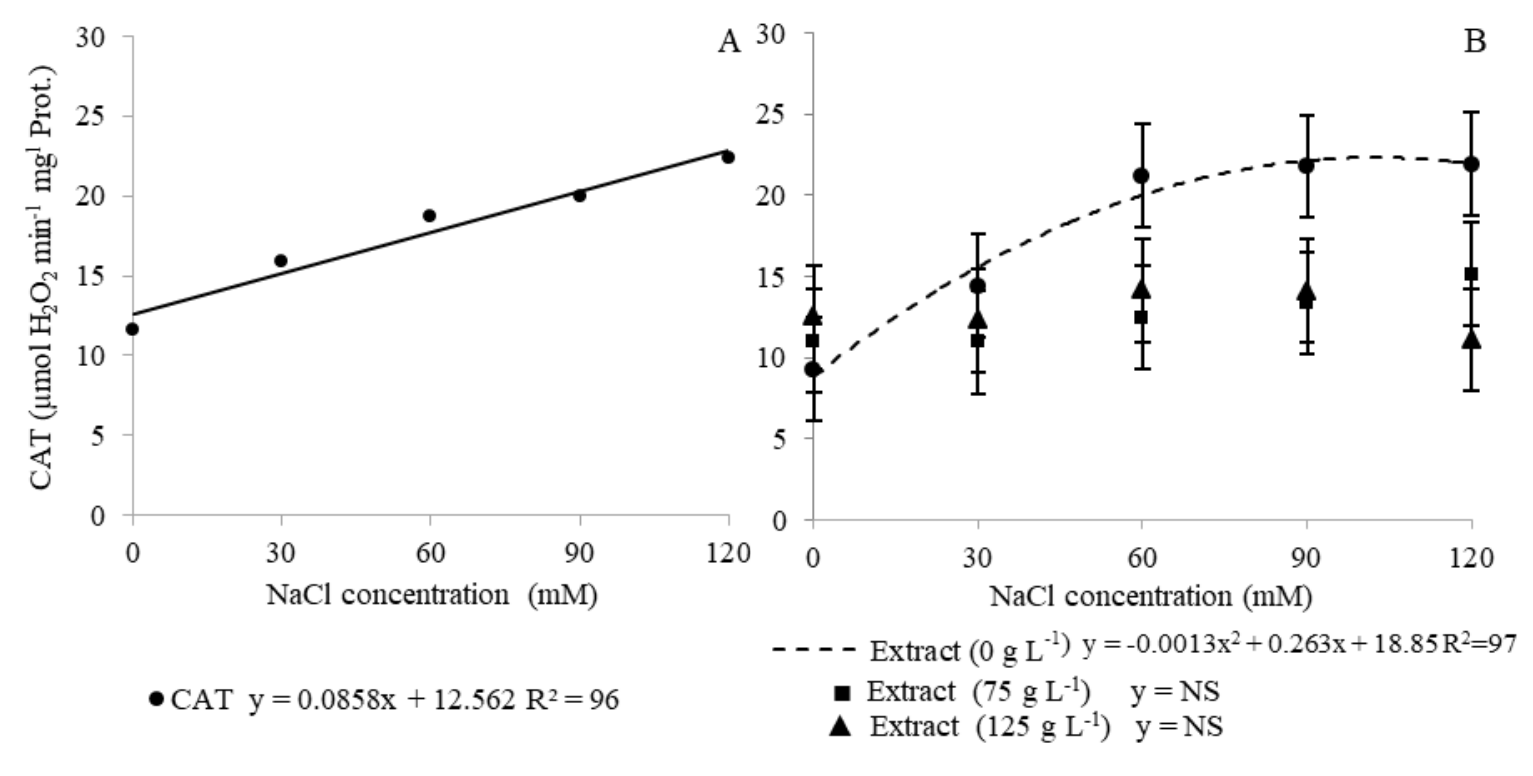

Figure 9: Catalase (CAT) enzyme activity in the aerial part $(A)$ and root $(B)$ of lettuce plants grown under different concentrations of purple lettuce leaf extract and $\mathrm{NaCl}$. The bars correspond to the MSD value (minimum significant difference) between the levels of the purple lettuce extract concentration factor ( $p$ $<0.05)$, overlapping bars indicate that the treatments do not differ statistically. 
It can also be observed, in relation to the aerial part, that the application of the extract helped by decreasing or avoiding oxidative stress, as there was a reduction in the concentration of hydrogen peroxide with the application of $125 \mathrm{~g} \mathrm{~L}^{-1}$ of extract, even with the increase in saline concentration (Figure 6A). The salt, when applied alone, caused an increase in $\mathrm{H}_{2} \mathrm{O}_{2}$, as the concentration increased, together with an increase in CAT activity (Figure 9), which is an effective enzyme in high concentrations of hydrogen peroxide and is considered essential in detoxification of ROSs in severe stress conditions [34]. In addition, there was also an increase in the flavonoid index with the increase in $\mathrm{NaCl}$ concentrations and the absence of lettuce extract (Figure 1B), which allows us to infer that these compounds increased their index to help defend the plant against stress caused by salt, together with the activity of the catalase enzyme, since flavonoids have the main function of protecting plants against oxidizing agents [35]. However, when the extract was applied, the opposite occurred, with the activity of the enzyme being lower and there was no difference in the flavonoid content as the salt concentration increased (Figure 1B), demonstrating that these compounds acted together with the enzymes antioxidants in defense of the plant.

In the root, it is possible to observe a greater activity of enzymes, mainly in the extract absence, since there is no synthesis of protective pigments, such as flavonoids, found in the aerial part of plants. However, as in the leaves, the concentration of hydrogen peroxide and the activity of antioxidant enzymes in the lettuce seedlings in which the purple lettuce extract was applied was lower in relation to its absence. This occurrence may be associated with the intervention of the extract in the absorption and translocation of sodium in the plant, with the joint action of flavonoids and antioxidant enzymes, thus preventing oxidative stress.

\section{CONCLUSION}

The extract of leaves of purple lettuce is efficient to reduce oxidative stress in lettuce plants submitted to salt stress, justified by the increase in the chlorophyll and nitrogen index and by the lower sodium concentration in the leaves. It also reduces the concentration of hydrogen peroxide and activity of antioxidant enzymes in both the aerial part and the root of lettuce seedlings, in relation to the application of salt.

\section{REFERENCES}

1. Barreiros ALBS, David JM, David JP. Estresse oxidativo: relação entre geração de espécies reativas e defesa dos organismos. Quím Nov. 2006;29(1):113-123.

2. Bray EA, Bailey-Serres J, Weretilnyk E. Responses to abiotic stresses. In: Buchanan BB, Gruissem W, Jones RL. (Ed.). Biochem Mol Bio Plants. 2000. Rockville: ASPP. p. 1158-1203.

3. Oba ET, Mariano WS, Santos LRB. Estresse em peixes cultivados: agravantes e atenuantes para o manejo rentável. Manejo e sanidade de peixes em cultivo, 2009. EMBRAPA Amapá-Macapá. p. 226247.

4. Gupta B, Huang B. Mechanism of salinity tolerance in plants: Physiological, biochemical, and molecular characterization. Int J Gen. 2014;2014(1):1-18, doi: 10.1155/2014/701596

5. Conn PF, Schalch W, Truscott TG. The singlet oxygen and carotenoid interaction. J Photochem Photobio B: Biol. 1991;11(1):41-4.

6. Damodaran S, Parkin K, Fennema OR. Fennema's food chemistry, 2008. 4. ed. Boca Raton: CRC Press. $1144 \mathrm{p}$.

7. Kähkönen MP, Heinonen M. Antioxidant activity of anthocyanins and their aglycons. J Agric Food Chem. 2003;51(3):628-633, doi: 10.1021/jf025551i

8.Collins A. Lettuce. In: AC diet food and nutrition. 2004. Available in http://www.annecollins.com/dietnutrition/lettuce

9. Rice-Evans CA, Miller NJ, Paganga G. Antioxidant properties of phenolic compounds. Trends Plant Sci. 1997;2(4):152-159, doi: 10.1016/S1360-1385(97)01018-2

10.Selene MM, Cavalcanti ESB, Costa SMO, Aguiar LA. Ação antioxidante de chás e condimentos de grande consumo no Brasil. Rev Bras Farmac. 2009;19(1B):315-320, doi: 10.1590/S0102695X2009000200023

11.Abbas SM, Akladious SA. Application of carrot root extract induced salinity tolerance in cowpea (Vigna sinensis L.) seedlings. Pak J Bot. 2013;45(3):795-806. 
12.Zhu JK. Salt and drought stress signal transduction in plants. Ann Rev Plant Biol. 2002;53:247-273, doi: 10.1146/annurev.arplant.53.091401.143329

13.Hoagland DR, Arnon DI. The water-culture method for growing plants without soil. California Agricultural Experimental Station, 1938. Circular. n. 347.

14. Tedesco MJ, Gianello C, Bissani CA, Bohnen H, Volkweiss SJ. Análises de solo, plantas e outros materiais. 1995. 2.ed. Porto Alegre, Universidade Federal do Rio Grande do Sul, 174 p.

15.Velikova V, Yordanov I, Edreva A. Oxidative stress and some antioxidant systems in acid raintreated bean plants. Plant Sci. 200;151(1):59-66, doi: 10.1016/S0168-9452(99)00197-1

16.Giannopolitis CN, Ries SK. Superoxide dismutase. I. Occurrence in higher plants. Plant Physiol. 1977;59:309-314, doi: 10.1104/pp.59.2.309

17. Nakano Y, Asada K. Hydrogen peroxide is scavenged by ascobate-specific peroxidase in spinach chloroplasts. Plant Cell Physiol. 1981;22(5):867- 880, doi: 10.1093/oxfordjournals.pcp.a076232

18. Azevedo RA, Alas RM, Smith RJ, Lea PJ. Response of antioxidant enzymes to transfer from elevated carbon dioxide to air and ozone fumigation, in the leaves and roots of wild-type and a catalase-deficient mutant of barley. Physiol Plant. 1998;104:280-292, doi: 10.1034/j.1399-3054.1998.1040217.x

19. Xu C, Mou B. Evaluation of lettuce genotypes for salinity tolerance. Hort Sci. 2015;50(10):1441-1446.

20. Wei Z, Julkowska MM, Laloe JO, Hartman Y, Boer GJ, Michelmore de RW, Van Tienderen PH, Testerink C, Schranz ME. A mixed-model QTL analysis for salt tolerance in seedlings of crop-wild hybrids of lettuce. Mol Breed. 2014;34:1389-1400, doi: 10.1007/s11032-014-0123-2

21. Paulus D, Dourado Neto D, Frizzone JA, Soares TM. Produção e indicadores fisiológicos de alface sob hidroponia com água salina. Hort Brasil. 2010;28(1):29-35, doi: 10.1590/S0102-05362010000100006

22. Silva RT da, Oliveira F de A de, Souza Neta ML de, Souza AAT, Oliveira MKT de, Medeiros R de CA, Paiva EP de. Índice de clorofila na cultura da rúcula submetida diferentes salinidades na solução nutritiva. Agrop Cient Semi-Árido. 2012;8(3):90-94.

23. Severo J, Tiecher A, Chaves FC, Silva JA, Rombaldi CV. Gene transcript accumulation associated with physiological and chemical changes during stages of strawberry cv. Camarosa. Food Chem. 2010;126:995-1000, doi: 10.1016/j.foodchem.2010.11.107

24. Esteves BS, Suzuki MS. Efeito da salinidade sobre as plantas. Oecologia Brasil. 2008;12(4):662-679.

25. Paulus D, Paulus E, Nava GA, Moura CA. Crescimento, consumo hídrico e composição mineral de alface cultivada em hidroponia com águas salinas. Rev Ceres. 2012;59(1):110-117, doi: 10.1590/S0034737X2012000100016

26. Taiz L, Zeiger E. Plant physiol. 2013. 5. ed. Porto Alegre: Artmed, 918 p.

27. Ünlükara A, Cemek B, Karaman S, Erşahin S. Response of lettuce (Lactuca sativa var. crispa) to salinity of irrigation water. New Zeal J Crop Hortic Sci. 2008;36(4):265-273, doi: 10.1080/01140670809510243

28. Neocleous D, Vasilakakis M. Effects of $\mathrm{NaCl}$ stress on red raspberry (Rubus idaeus L. and Autumn Bliss L.). Sci Hort. 2007;112:282-289, doi: 10.1016/j.scienta.2006.12.025

29. Willadino L, Camara TR. Tolerância das plantas à salinidade: Aspectos fisiológicos e bioquímicos. Enciclo Biosf. 2010;6(11):1-23.

30. Barassi CA, Ayrault G, Creus CM, Sueldo R, Sobrero MT. Seed inoculation with Azospirillum mitigates $\mathrm{NaCl}$ effects on lettuce. Sci Hort. 2006;109:8-14. doi: 10.1016/j.scienta.2006.02.025

31. Eraslan F, Inal A, Savasturk O, Gunes A. Changes in antioxidative system and membrane damage of lettuce in response to salinity and boron toxicity. Sci Hort. 2007;114:5-10, doi: 10.1016/j.scienta.2007.05.002

32. Pérez-López U, Miranda-Apodaca J, Muñoz-Rueda A, Mena-Petite A. Lettuce production and antioxidant capacity are differentially modified by salt stress and light intensity under ambient and elevated $\mathrm{CO}_{2}$. J. Plant Physiol. 2013;170:1517-1525. doi: 10.1016/j.jplph.2013.06.004

33. Mohammadi P, Khoshgoftarmanesh AH. The effectiveness of synthetic zinc ( $\mathrm{Zn}$ )-amino chelates in supplying $\mathrm{Zn}$ and alleviating salt-induced damages on hydroponically grown lettuce. Sci Hort. 2014;172:117-123. doi: 10.1016/j.scienta.2014.03.047

34. Barbosa MR, Silva MMA, Willadino L, Ulisses C, Camara TR. Geração e desintoxicação enzimática de espécies reativas de oxigênio em plantas. Ci Rur. 2014;14(3):453-460, doi: 10.1590/S010384782014000300011

35. Lopes RM, Oliveira TD, Nagem TJ, Pinto ADS. Flavonóides. Biotec Ciên Desen. 2010;3(14):18-22. 